\title{
Strengthening Fisheries Institutions for Overcoming Poverty in Bantul Regency
}

\author{
$1^{\text {st }}$ Supriyanta $^{1}, 2^{\text {nd }}$ Oktiva Anggraini ${ }^{2}$ \\ \{waskito63@gmail.com ${ }^{1}$,oktivabiyan@yahoo.co.id ${ }^{2}$ \} \\ Faculty of Economics University of Widya Mataram Ndalem Mangkubumen KT III/237 Yogyakarta ${ }^{1}$, \\ Affiliation, Faculty of Social Political University of Widya Mataram \\ Ndalem Mangkubumen KT III/237 Yogyakarta ${ }^{2}$
}

\begin{abstract}
This research identified the performance's marketing of fishery busines in Bantul regency and the factors that influenced of accessibility of them in e-commerce. With descriptive qualitative research design, the data collection techniques: in-depth interviews; Literature study, observation, and FGD. Data analysis techniques with data reduction stages, the data presentation, and conclusions. The results showed that fishery business is still classified as early adopters in e-commerce. Strengthening of capacity for fishery busines in developing e-commerce needs to be done Immediately. Department of Agriculture of the Food and Marine Fisheries in Bantul Regency can further develop websites to support e-commerce and Facilitate Reviews These activities in cooperation with relevant stakeholders.
\end{abstract}

Keywords: E-Commerce, Fisheries, Institutions, Strengthening The Capacity.

\section{Introduction}

Micro, Small and Medium Enterprises (SMEs) constitute the largest group of economic actors in the Indonesian economy and proved to be a national economic safety valve in times of crisis as well as a dynamic factor of economic growth. In 2015, recorded the number of SMEs in Indonesia as much as 57,9 million with the contribution of GDP (Gross Domestic Product) of $58,92 \%$ and a contribution to the employment of $97,30 \%$. DIY as one of the pioneers of the export-based SMEs, the revenue potential of the industry is very encouraging. The quantity of SMEs in the province continues to increase every year. The Departement of Industial and Commerce in DIY 2013 showed that the food industry and the craft became one of supporting the tourism sector DIY. In 2013 there were 22.970 units in the DIY craft businesses with employment 76.028 people and the investment value Rp.142.688.995,-. While the production value reached Rp.497.988.944,-. Nevertheless, SMEs in Yogyakarta face a number of challenges. UGM FISIPOL ASEAN Studies Center (Suharko, 2015) in his research revealed that the main obstacle to SME development and marketing related to capital and labor skills and lack of information. Coverage sale in DIY is still dominant, $54,15 \%$. The product is still limited mostly at the local level and many who do not have a direct link with the modern market (supermarkets). Approximately 28,8\% utilizing the Internet to promote their products, the rest still use conventional methods of marketing products (Nisa, 2015).

Data survey of Indonesian Internet Service Provider Association (APJII) in collaboration with the Central Statistics Agency (BPS) in 2013 that 77,81 percent used the Internet to search 
for goods and services. Internet users in Indonesia in 2013 amounted to 71,19 million people, an increase of 8,19 million people (13 percent) from the previous year, amounting to 63 million people. The positive rising trend provides interesting opportunities for the use of ecommerce in the marketing of goods and services in Indonesia. Including businesses SMEs.

E-commerce called electronic commerce is the use of computers and communications networks to implement business processes. Beginning of the use of e-commerce is to connect businesses known as Business-to-Business or B2B. But in its development, e-commerce can be used to connect between businesses with consumers known as Business to-consumer or B2C (McLeod and Schell, 2008). Manzoor (2010) states that e-commerce is a commercial activity (sales, purchase, transfer, exchange of products, services, and dissemination of information) undertaken in the business, both among businesses and businesses with consumers.

A number of studies showed that the information input markets needed, especially to determine: (1) the source of the raw materials required, (2) the price of the raw material to be purchased, (3) where and how to obtain venture capital, (4) where getting labor professional, (5) the level of wages or salaries eligible for workers, (6) where it can acquire the tools or machines required (McLeod and Schell, 2008; Manzoor, 2010; Stockdale, 2012). Market information is complete and accurate can be used by SMEs to plan their business properly, for example: (1) a product design that consumers preferred, (2) determine the competitive prices on the market, (3) determine the market that will be addressed and the many benefits more. Therefore the role of government is essential in driving the success of SMEs in gaining access to expand its marketing network.

The phenomenon was also discovered during the pre-survey research team in Bantul district, which is encouraging the performance of SMEs, including SMEs in the coastal fisheries. Currently, there are about 200 more SMEs fisheries, spread over seven TPI Bantul, processed fishery products that can support the local tourism industry. Currently, the development of SMEs fisheries experienced a number of challenges due to increasing competition in the fishing industry and a limited ability to expand your marketing reach. For that, we need a variety of efforts to improve business performance in order to be able to strengthen and improve the economy of coastal residents.

Departing from the above issues would be explored further draw on the performance of SMEs fishery districts of Bantul in marketing their products and the factors that influence SME access Fishing in the use of information technology.

\section{Research Method}

This study used a qualitative design. Primary data collection included structured interviews, questionnaires, focus group discussions and direct observation. FGDs were held in four (4) locations TPI with guest speaker invited representatives of stakeholders. Sampling is purposive sampling, ie the chairman, members and officials of SMEs fisheries. To ensure data validity, data source triangulation was done by collecting similar data from several different data sources. Data source were developed and stored so that at any time can be traced back if desired verifications. 


\section{Result}

\section{Description of the Research Site}

Marine and fisheries sector Bantul district has a very high economic potential. Potential of marine fisheries management in Bantul continue to be pursued for the benefit of society without leaving aspects of sustainability. Improving the economy of the community who attended awareness of the importance of fish consumption creates the implication of increased demand for fish and other dairy products. This situation is an opportunity for the development of marine and fisheries sector, especially in Bantul.

For 2015, fisheries production performance achievements qualify as low, while for aquaculture production falls within the criteria quite well. Achievement of fishing production when compared with other regencies/cities in Yogyakarta, Bantul contributed 13,32\% to the total fisheries production DIY. As for aquaculture production, Bantul to provide a contribution of $16,38 \%$ of the total aquaculture production DIY.

Most aquaculture is developed with the media pool in all the districts in Bantul district government, followed by the media fields and tarpaulins. With the change of use of productive land into residential areas, fishing grounds are limited. One solution to cope with the utilization of non-productive lands or marginal lands as cultivation media in the field of fisheries, such as catfish with a tarp.

Resilience catfish in water that does not flow easily applied make catfish farming despite the narrow and dry land. Catfish farming is not costly, easier and shorter maintenance time, so quickly deliver results for empowerment's program. Unlike the other species that are susceptible to diseases, catfish do not require special attention when maintenance.

Catfish farming in drylands using pool tarp in Bantul is the best strategy. Land development for operational and business segmentation in accordance with the demand and market potential. With this strategy, the growth and development of enterprises can increase revenue catfish farmers by harnessing the power and opportunity to do the pattern of harvest and cultivation, as well as feed efficiency. This strategy needs to be done with high caution against the threat of the spread of disease and competitors from outside the area. African catfish seed production in Bantul amounted to 32.804 .783 tail in 2015 followed by as many as 24.157.027 tail carp, tilapia tail 4.382.099 and 2.407.886 decorative fishtail 1.328.770 tons, 707.639 tons of carp, tilapia 378.681 tons, 141.228 tons Tawes and carp 41.074 tons.

Potential catfish farming developed than other fish commodities in Bantul. Realization of production in 2015 for example, production totaled 1.328 .770 million kilograms, at most compared to carp that production reached 707.639 kilograms, indigo, Tawes, and others. Likewise with African catfish seed, reached 32.804.783 kilograms. Fish disease is endemic and $\mathrm{pH}$ levels are sometimes less appropriate result commodities other fish is less developed in Bantul.

Realization of fishery products of the most prominent in the sub-Imogiri, Banguntapan and Bantul. For the seed activity, dominated four districts namely Imogiri, Banguntapan, Djetis, and Kretek. While the fish rearing activities in the district of Bantul, Banguntapan and Imogiri. With the potential, setting development priorities PUMP each year in the districts of Bantul directed at the development of commodity catfish and carp. Kretek district area has the potential marketers, include 516 people, followed by 500 people Jetis sub-district, district Pundong 484 people and the smallest region potential is subdistrict Dlingo with 209 people. While the region is most fishermen Kretek sub-district, ie 74 people, followed by Sanden Srandakan 29 people and 13 people. Groups of processors and marketers the largest fish in the region of Kretek 89 people, Sewon sub-district followed 49 people. The conditions illustrate 
that coastal communities in the districts of Bantul more engaged in the aquaculture sector. Fishing profession only as a sideline profession in addition to farming and animal husbandry.

\section{Product Marketing SMEs}

Aquaculture in coastal communities Bantul regency, followed by various post-harvest activities are encouraging. Armed with an entrepreneurial spirit who is good enough to encourage a number of cultivator develop food processing business, souvenir with raw fish or open a culinary shop business. Various products have been marketed in traditional markets and supermarkets nearby.

They have realized the importance of trademarks and brands already have etiquette. Registration etiquette brands showed relief efforts adding value to the product. The brand as a symbol of product sold as well as one of the placements bargaining position over competitors' products. Determination of the brand provides the power of a product and to differentiate between products. Marketing areas include Bantul and Yogyakarta through personal connections /relationships. The marketing system that is run by a joint Business Group (KUB) marketers and fish processors are of two kinds, marketed itself in the traditional way and new media as well as through the association Projo Mino Bantul. This association accommodate the interests of economic, social and political members. Through this association, the articulation of the interests of marketers and fish processors in Bantul voiced by relevant agencies and Parliament Bantul regency. This is consistent with the opinion of Eaton (1986), that Projo Mino as an organization can be called the institution if it has developed the ability to act as a representative of the broader community by providing functions and services are valuable, one of which increase the utilization of natural resources,

Based on the observation of many fisheries researchers SMEs that have not been able to adapt and improve competitive advantage. It may, therefore, be a challenge to improve the competitiveness of SMEs, on the institutional side and in terms of the resulting product. The structure of businesses until now dominated by the informal micro-enterprises. The perpetrators of this business have no assets, quality of human resources, access to finance and productivity are very limited. Therefore the related increasing ability and competitiveness, SMEs have to race in some ways, the increasing of competent human resources/human capital, improve product quality, conduct business efficiency, enhance business partnerships and build a strong network of marketing communications.

Through Projo Mino group, an important role for government is more geared to facilitate several things including licensing, facilitating access to raw materials, technology, and information, technical assistance in the form of training, mentoring, advocacy, while creating a favorable climate, and good capital facilitation.

On the other hand, limited funds for marketing communications causes the efforts of SMEs often encounter obstacles in reaching the wider consumer, as was able to do a largescale company. Small-scale companies use marketing communication is still very simple through word of mouth marketing communication, or more commonly known degan term 'word of mouth'. An exciting development, the SMEs souvenirs made from stingray and fish culinary entrepreneurs mostly have combined new media, word of mouth promotion and sale through the association Projo Mino. Feedback on the new media so perceived by some employers in the form of increased sales turnover per month, product diversification, expansion of the network, the higher the confidence to participate in exhibition and sale of the water. In terms of network expansion, is in line with the opinion Manzoor (2010) that the ecommerce applications resulted in the exchange of products, services, and information dissemination is done in the business, both among businesses and businesses with consumers. 
With the implementation of e-commerce will help entrepreneurs in accessing sources of raw materials required, the price of raw materials to be purchased and market opportunities. Based on data from the FGD and DKP 2016 Annual Report documents a number of issues that arise in the network of SMEs fisheries:

a. The lack of a group of institutional fish processors and marketers solid thus not been able to produce a processed fish products are of good quality and have not been able to meet the tastes of the market according to the amount needs and has not yet formed a market network that is able to absorb the results of the production as needed.

b. A group of institutional fish processors and marketers rely on raw materials of fish, fish seeds were obtained from outside the area thereby increasing the production costs for transport effect on price competition.

c. Limitations of the use and handling of fish processing technology has not used the cold chain system so that the products produced relatively declining.

Table 1

\begin{tabular}{|l|l|l|}
\hline No. & Information & $\%$ \\
\hline 1. & $\begin{array}{l}\text { Do not have HR personnel in the field of IT (Information } \\
\text { Technology) }\end{array}$ & 10 \\
\hline 2. & Lack of understanding of the internet & 65 \\
\hline 3. & Not according to the product & 5 \\
\hline 4. & Not having a business strategy in the Internet & 5 \\
\hline 5. & Do not believe the transaction on line & 5 \\
\hline 6. & Less useful for entrepreneurs & 10 \\
\hline
\end{tabular}

Primary Data: 2017 (the data processing of the 100 respondents SMEs fisheries)

According the table 1 it appears that the majority of SMEs have not yet implemented fishery e-commerce,both in financial and transaction management sales / marketing. The obstacles faced by, among others: the high cost of internet connection; do not have HR personnel in the field of IT (Information Technology); does not have a business strategy via the Internet; less useful for entrepreneurs; do not trust the security of electronic transactions; not in accordance with the products offered by employers and lack of understanding in the use of the Internet (data from interviews with a number of informants fishery SMEs, August 2017).

While the external side, the inhibiting factor is that the original Office handles fishery SMEs, Department of Marine and Fisheries began in 2017 have joined forces under the auspices of the Department of Agriculture, Food, Marine and Fisheries Bantul. By making no independent position and more often burdened by paperwork, resulting in strengthening the capacity of SMEs fisheries network was inhibited. Whether conducted by the Association of Mino Projo or through other fishery groups. The observation of researchers co indicates that the information system and website Department of Agriculture, Food, Marine and Fisheries Bantul less help farmers and SMEs in accessing market information, production inputs, consumer trends, marketing, management of disease and pest / crop livestock, market opportunities, and market price.

Based on these constraints, measures to strengthen the capacity of SMEs fisheries (based FGD stakeholder fisheries, August 2017) include:

1. SME entrepreneurs both individually and collectively need to sharpen themselves through training IT (information technology). The confidence they need to be confirmed by the ability and skill in packaging the product so worthy to be uploaded on-line. Packing 
attractive and safe products, the availability of the brand, how to shoot the products are small examples that can add value to their products online.

2. Department of Agriculture data updating website Food Marine and Fisheries Bantul will be able to help SMEs access to market information, production inputs, consumer trends, marketing, management of disease and pest/crop livestock, market opportunities, and market price.

3. Hold students of Community Services Program to help e-commerce applications.

4. For users of IT applications for business, should begin to be developed that e-commerce is not only to support the marketing, but also for the search of raw materials, mapping, controlling price stability and expand business networks.

\section{Conclusion}

The DIY culinary potential in particular in the districts of Bantul is part of the creative industries are being developed by the government. When many culinary potential of processed fishery that is not heard, or known by the public even though taste and form of presentation of promising and lucrative, it is very unfortunate. The problem lies in the lack of promotion of such products to the general public. Henceforward, capacity building such as training of IT application in SMEs fisheries groups and individuals interested in developing e-commerce needs to be done immediately. Bantul in this case the Department of Agriculture Food and Fisheries Marine can further develop the website to support e-commerce and facilitate such activities in collaboration with relevant stakeholders.

\section{Reference}

[1]. Eaton, Joseph W. 1986. "Guidelines for Formulation Development Theory 'in Development Agencies and National Development: From Concept to Application. Editor JW Eaton. UI Press. Jakarta. It 157-167.

[2]. Manzoor, A. 2010. E-commerce an Introduction. LAP LAMBERT Academic Publishing GmbH \& Co. KG. Dudweiler Landstr. 99.66123. Saarbrucken, Germany.

[3]. McLeod, R. and GP. Schell, 2008, the Management Information Systems 10th Edition. Salemba Four. Jakarta.

[4]. Nisa Agistiani Rahman, 2015, the Opera-Utilization Technology as Developing Effort Product Competitiveness of SMEs in the book Small and Medium Enterprises in whirls MEA, Opportunities, Challenges and Readiness, Editor: Suharko, Subarsono. Yogyakarta: ASC FISIPOL UGM.

[5]. Stockdale, R., Ahmed, A. dan Scheepers, H. 2012, Identifying Business Value from the Used of Social Media an SME Perspective, Pacific Asia Conference on Information System. Association for Information System, Electronic Library.

[6]. Suharko, Subarsono (editor), 2015, Small and Medium Enterprises in whirls MEA, Opportunities, Challenges and Readiness, Yogyakarta: ASC FISIPOL UGM.

[7]. APJII, 2012, the Indonesian Internet profiles 2012. Reports survey results Indonesian Internet Network Users Association. Jakarta. 